\title{
Accommodation Beyond Self-Interest: Identity, Policy Paradigms, and the Limits of a Rationalist Approach to EU Policy Towards Central Europe
}

\author{
Ulrich Sedelmeier, Central European University/Budapest
}

Paper presented at the ECSA Biennial International Conference Pittsburgh, 3-5 June 1999

Panel Session 7. The Politics of Eastern Enlargement: Constructivist Explanations

Draft only. Please do not cite without permission; comments still very welcome.

International Relations

and European Studies Department

Central European University

Nádor u. 9

H-1051 Budapest

e-mail: sedel@ceu.hu

\begin{abstract}
:
The paper argues that rationalist approaches cannot fully account for the European Union's policy towards the countries of central and eastern Europe (CEECs). EU policy accommodates the preferences of the CEECs to a greater extent than an account based on purely material interests on the part of the EU would expect. The paper argues that we need to take ideational factors into account to explain the outcome, namely the EU's collective identity and sectoral policy paradigms.

EU identity towards the CEECs includes the notion of a "special responsibility" that proscribes purely self-interested behaviour by policy-makers acting on behalf of the $E U$, and prescribes a degre of accommodation of the CEECs' preferences in EU policy. This aspect of the EU's collective identity becomes politically salient through the advocacy of policy options that are in line with this identity. In the case of the association policy, these policy atvocales were primarily located inside the Commission, with a loose supportive coalition among the member state foreign ministries.

However, to understand how such actuocacy of an accommodation of the CEECs' preferences affects policy across the various sub-areas of the association policy, we need to understand which factors mediate this policy impact. The paper argues that the policy paradigms that underpin EU policy in the various policy areas covered by the association policy are a crucial mediating factor, which can only be captured by a sociological institutionalist approach.
\end{abstract}




\section{Introduction}

This paper analyses the European Union's (EU) association policy towards the countries of central and eastern Europe (CEECs). The central analytical claim is that rationalist approaches in Political Science cannot fully capture the development of the association policy. I argue that the analysis needs to include two types of ideational factors. Specifically, this concerns, first, the role of a collective EU identity towards the CEECs, i.e. the norms embedded in the EU's institutional structure that affect the collective self-understanding of EU policy makers in their interactions with the CEECs. The second type of institutional factors relates to the role of policy paradigms, i.e. the respective sets of ideas that underpin EU policy in the various policy areas affected by the association policy.

The paper conceptualises the association policy as a "composite policy": while the association policy constitutes the "macro-policy", it draws its substance from the range of "meso-policy" areas that constitute it. The concept of a "composite policy" allows (i) to distinguish between the different types of institutional factors that shape preference formation at the levels of the macro- and meso-policies, and (ii) to identify three aspects of the structure of the composite policy that mediate the policy impact of the preferences of the macro-policy makers, and thus, as I will argue, of collective EU identity towards the CEECs.

This paper proceeds as follows. Section 2 outlines the shortcomings of rationalist approaches in explaining the association policy. Section 3 suggests that in order to capture more fully the factors that shape the preferences and behaviour of those policy makers with overall responsibility for the association policy, the role of the collective EU identity towards the CEECs has to be taken into account. I argue that this collective EU identity inclines these policy makers towards accommodating the CEECs' preferences to a certain extent in EU policy. In line with social constructivist approaches, I do not claim that EU identity as such determines policy outcomes, but that it affects preference formation and behaviour by limiting the range of policy options that seem appropriate to these policy makers.

However, to analyse simply the preferences of this group of policy makers is insufficient for an explanation of the association policy. These policy makers cannot take decisions on the substance of the association policy in isolation. Such decisions have to be delegated to, or negotiated with, other groups of policy makers that have the primary responsibility for the range of EU policy areas that the association policy affects. The association policy process is therefore characterised by horizontal policy coordination between these different groups of policy makers. In section 4, I therefore suggest that in order to take account of this " characteristic, the association policy should be analysed as a "composite policy:" 
I point at three key aspects of the structure of the composite policy that affect the relative ability of the different groups of policy-makers to influence policy outcomes: (i) the structure of the policy coordination process between macro- and meso-policy makers; (ii) the policy paradigms that underpin EU policy in the various meso policy areas and shape the preference formation of the meso policy makers; and (iii) the relationship between public policy makers and societal actors in the meso-policy areas.

The empirical analysis consists of three parts. Section 5 presents evidence from the overall development of the association policy, as the macro-policy. Section 6 concerns policy in two specific meso areas of the association policy: EU trade liberalisation in the steel sector, and EU policy for the regulatory alignment of the CEECs with the internal market. Section 7 summarises the findings.

\section{Shortcomings of rationalist approaches to the association policy}

Most analyses of the association policy rest at least implicitly on a liberal intergovernmentalist approach to studying the EU (Moravcsik 1993). In these analyses, the association policy is the result of a strategic bargaining process among utility-maximising actors (Haggard et al 1993. Nicolaidis 1993, Guggenbuhl 1995, Niblett 1995, Shaffer 1995, Friis 1997). The policy outcome is constrained by bargaining at three analytically distinct levels: between the EU and the CEECs, between the different member states, and between member. state governments and domestic groups. Policy then reflects the relative bargaining power of each group of actors, and the interaction between levels.

However, while such approaches provide insight into certain important patterns of the policy process, the extent to which EU policy accommodates CEEC interests does not seem to conform with rationalist. In essence, a rationalist, interest-based approach might explain an accommodation of the CEECs' interests in three ways: (i) the bargaining power of the CEECs could be sufficient to extract concessions from the EU. This is clearly not to the case given their strategic and material capabilities and bargaining assets. Even in the absence of strong bargaining power of the CEECs, their interests could be accommodated, if their interests coincide with either (ii) the broader political or economic interests of the most powerful member states, or (iii) the economic interests of the predominant domestic groups. Neither seems convincing in the case of the association policy. Even if an accommodating policy did serve the interest, of e.g. the German government, other member states, for which this is not the case, could exercise their veto power under the unanimity rule that applies to association agreements and decisions on enlargement. And to the extent that domestic pressure has been articulated, if has been predominantly a constraining factor on policy. 
A further puzzle from a rationalist perspective is the way in which EU policy makers continuously couched pledges of EU support for the CEECs in strong normative language. Statements by successive European Council meetings, as well as by individual officials, asserted a "special responsibility" of the EU towards the CEECs. The normative link between EU responsibility and the collective identity of the member state policy makers in the EU was most clearly articulated in the statement by Karl Lamers (1995: 2), foreign affairs spokesman of the CDU/CSU faction in the Bundestag:

Die Erweitenung der Europäischen Union ist nicht nur eine Fragc unseres Interesses, sclion gar nicht nur eine Frage des deutschen luteresses, sondern auch cine Frage der Moral, das heißt unseres Selbstverständnisses. Habcn wir doch jahırzchntclang den unfreicı curopäisclıcn Völkcrn feicrlich versprochen, sie in unsere Geneinschaft aufzunchmen, und kann es doch auch gar keinen Zweifel daran geben, daß sie cinen listorisch, moralisch und kulturell begründeten Anspruch darauf haben. Wenn wir dieses Versprechen nicht einhalten, so würden Moral und Selbstverständnis einen nicht wieder gutzumachenden "Bruch" erfalıren, und zugleich wäre unser Interesse, eben unser Interesse an einer stabilen Umwell gefälırdet (Lamers 1995: 2). ${ }^{1}$

From a rationalist perspective, such statements are either entirely insignificant, since they are cheap talk, or used to conceal underlying self-interested motives. Arguably, this might explain why German policy makers use such normative language. However, it is not obvious why it also characterises collective European Council statements, let alone those by representatives of member states for which enlargement is generally expected to entail greater costs than direct benefits. From a rationalist perspective, statements as the following by the Spanish Permanent Representative to the EU, Javier Elorza, must seem puzzling.

As far as Spain is concerned ... the acceptance of enlargement is not just a legal question, but a political and moral one. No country knows better than Spain the meaning of EU membership (Elorza 1997: 9).

A further feature of the association policy creates a puzzle, not necessarily for a rationalist approach as such, but certainly in their liberal intergovernmentalist version. Frequently the policy debate was not characterised by national dividing lines and by inter-state bargaining. Rather, the lines of debate ran across national governments and the Commission, frequently opposing policy makers responsible for external relations to those concerned with sectoral issues (see also Niblett 1995, and Torreblanca 1997 for similar observations).

\footnotetext{
1 "The enlargement of the European Union is not just a question of our interest, let alone just a question of Germany's interest, but also a moral question, this is, of our understanding of ourselves. For decades we have promised the captive peoples of Europe that we will welcome them in our community, and there cannot be any doubt that they have a historical, moral and cultural claim to this. If we do not keep this promise, both our moral position and our self-understanding would be 'broken' irreparably; and at the same time, our own interest, which lies precisely in having a stable environment. would be threatened [my translation]."
} 


\section{The role of a collective EU identity towards the CEECs}

While this is not to downplay the extent to which selfish interests and the distribution of power - between the member states, different domestic groups, and between the EU and the CEECs affected policy outcomes, I argue that other approaches that take account of non-material factors are necessary to complement such an analysis. Hence, this chapter argues that EU policy towards the CEECs is neither simply a set of trade negotiations, nor a narrow case of joint EU foreign policy towards its "near abroad." Accommodation of CEEC interests goes beyond a mere acknowledgement of a "situational interdependence" (Keohane 1991: 229) between the member states and the CEECs. EU policy towards the CEEC is not simply about material interests and the material bargaining assets of the different actors. It is also about the definition, and the enactment, of the EU's collective identity. '

More general norms embedded in the EU's institutional structure, or components of a collective EU identity that might affect policy towards the CEECs can be traced back to the notion of the broader European vocation of the EU, and its particular role in supporting democratic and market economic development. Not only do these norms resonate particularly in the case of the CEECs. They have been reinforced and given more concrete substance in statements by EU policy makers about the EU's role towards the CEECs. From the origins of the EU throughout the Cold War period, such statements stressed the EU's solidarity, and the involuntary nature of the exclusion of the CEEC from the integration process. The range of policy statements in response to the changes in the CEECs in the late 1980 s reaffirmed this commitment and the strongly normative pledges of EU support for the CEECs' transformations reinforced this discourse. Successive European Council meetings, as well as individual officials asserted a "special responsibility" of the EU towards the CEECs, in that the EU has a "historical opportunity" to overcome the division of the continent, and an obligation to actively support democratic and economic development in the CEECs and their integration with the EU: The notion of an EU responsibility towards CEEC has become a central feature of the EU discourse on policy towards the CEECs.

I suggest that this diffuse notion of EU responsibility towards the CEECs constitutes a component of the collective identity of EU policy makers. Compliance with this self-image is an important aspect of EU policy. The enactment of this EU identity affects policy through regulative norms that suggest that certain types of behaviour are more "appropriate" than others. In the case of the EU policy towards the CEECs, the component of EU identity that implies a responsibility for the $\mathrm{CEEC} s$ is enacted through compliance with a diffuse regulative norm that proscribes purely self-interested behaviour, and prescribes to consider the CEECs' interests in policy. Accommodation of the interests of the CEECs is thus not only the result of convergence between dominant EU and CEEC interests, but also an important evaluative 
standard of policy in its own right. Collective EU identity towards the CEECs, and the regulative norm of accommodating the CEECs' interests in EU policy, do not determine policy outcomes. But they might structure the "realm of possibilities" for available policy options (Price and Tannenwald 1996: 148-149; see also Klotz 1995: 461-462), by excluding certain options as inappropriate, and reinforcing the legitimacy of others. In this sense, the regulative norm provides a necessary condition, in combination with more self-interested motivations, for EU policy to accommodate the CEECs' interests.

However, EU identity and the regulative norm of accommodation resonate more with some policy makers than with others. In essence, questions of EU identity resonate most strongly with policy makers that represent the EU externally, and towards the CEECs in particular. Those are the heads of state and government and the foreign ministers of the member states, as well as Commission officials responsible for external relations and for policy towards the CEECs. The resonance is particularly strong for the latter, since identification with the EU as such is a much greater part of their multiple social identities. By contrast, EU identity towards the CEECs is a much less important factor in shaping the preference formation of sectoral policy makers, both inside the Commission and in the member state governments.

This uneven effect of a collective EU identity towards the CEECs across different groups of. EU policy makers is crucially important for the association policy. The policy makers with overall responsibility for the association policy are the ones who are most receptive to those regulative norms, but they do not decide policy autonomously. Decisions about the concrete substance of the association policy in the various areas that the association policy comprises have to be coordinated with policy makers that have primary responsibility for these areas. The policy impact of collective EU identity towards the CEECs thus depended on the ability of the former group of policy makers to influence policy. A key determinant of policy impact is therefore the structure of the policy-making process, as it determines access to the policy process, and thus the degree of direct pressure that can be brought to bear on it.

\section{The association policy as a composite policy and the role of policy paradigms}

I suggest that the structure of the association policy can be conceptualised as a "composite policy," which is constituted by a range of distinctive "meso-policies". Policy making is characterised by the requirement of horizontal policy coordination between policy makers with overall responsibility for the association policy - the macro-policy - and those in charge of specific meso policy areas. The requirement of horizontal policy coordination suggests that the literature on policy coordination within national ministerial bureaucracies (see e.g. Scharpf 1993. Mayntz 1993) can provide important clues for the formal aspects of the structure of the 
composite policy that mediate the impact of an advocacy of an accommodation of the CEECs' interests.

The first aspect concerns the structure of the policy coordination process between macro- and meso-policy makers, namely to what extent coordination is centralised/hierarchical, fragmented, or negotiated. The more centralised the policy making process, i.e. the more it is characterised by hierarchical coordination, which either explicitly subordinates meso concerns or implicitly circumvents them, the greater the influence of the policy preferences of the macro policy makers on policy. The more fragmented/negotiated the coordination process, the more the preferences of the meso-policy makers should be reflected in the policy outcomes in the meso-policy areas. The influence of the preferences of the meso-policy makers should be greatest, if fragmentation means that they can autonomously decide policy, or if negotiated coordination is characterised by a bargaining process in which meso-policy makers have the power to veto policy changes ("negative coordination").

The second aspect of the structure of the composite policy relates to the structure of the respective meso-policy areas, with regard to the relationship between public and societal actors in these areas. Even if the macro policy makers prevail over meso policy makers in the policy coordination process, opposition from strong interest groups in a certain policy area can militate against the implementation of policy changes.

With regard to the relationship between public policy makers and societal actors, however, this paper argues - in contrast to rationalist approaches in comparative politics, or the liberal intergovernmentalist view of domestic politics - that public policy makers do not simply act according to the interests of the strongest societal groups. Rather, public policy makers have preferences of their own, and might pursue these even against societal pressure (see also e.g. Evans et al 1985). In line with historical institutionalist approaches, I argue that these preferences are to an important degree shaped by ideas that underpin their understanding of policy in their respective areas of responsibility. To characterise these sets of ideas that shape policy makers preferences, I use Peter Hall's concept of policy paradigms (Hall 1993). Such policy paradigms might function as an additional filter that constrains the scope for accommodation. However, other policy paradigms might favour policy options that are in line with an accommodation of CEEC interests. An accommodation of CEEC interests within specific meso policies might thus be possible, despite strong opposition from domestic groups in this sector. An important question is therefore whether the policy advocates can challenge dominant policy paradigms, or form a strategic alliance with policy makers in the meso area that promote the emergence of a competing, more compatible, policy paradigms: 
In sum, the three main aspects of the composite policy that mediate the policy impact of the respective preferences of macro- and meso-policy makers, and hence facilitate or obstruct the accommodation of the CEECs' preferences, are: (i) the structure of the policy coordinating process between macro and meso policy makers, namely the degree of fragmentation/centralisation of this process; (ii) the policy paradigms that underpin EU policy in the various meso-policy areas and shape the preference formation of the meso-policy makers, namely the degree of compatibility of policy options preferred by macro policy makers and the ideas that constitute the policy paradigms; and (iii) the relationship between public policy makers and societal actors in the meso-policy areas, namely the strength/weakness of societal groups in influencing meso-policy makers.

The following sections provide an overview of the empirical analysis. Section 5 presents evidence from the overall development of the association policy, i.e. the macro-policy. Section 6 summarises the findings of two meso-policy areas: the liberalisation of steel trade, and the regulatory alignment of the CEECs with the internal market.

\section{The overall development of the association policy}

The association policy developed over three key stages. The first stage were the negotiations of the first set of bilateral Europe Agreements (EAs) between the EU and individual CEECs that were signed with Poland, Hungary, and Czechoslovakia in December 1991. These EAs formed the blueprint for the agreements that were subsequently signed with the other CEECs. Essentially, the EAs provided for the establishment of a free trade area in industrial products, political dialogue, and cooperation in a broad range of policy areas. They were, however, criticised for the limitations of the concessions in the "sensitive sectors" of agriculture, textile, and coal and steel, as well as for the unwillingness of the EU to commit itself in the agreements to the eventual accession of the CEECs. The second stage of policy development was the endorsement of the CEECs' eventual accession as an objective shared by the EU at the Copenhagen European Council in June 1993. The third stage was the approval of a strategy to prepare the associated CEECs for accession by the Essen European Council in December 1994. It marked a shift in the perspective of policy from an association policy to an enlargement policy, which was confirmed in the start of accession negotiations in March 1998.

\section{The relevance and limits of a rationalist approach}

Rationalist approaches highlight key factors that shaped the development of the association policy, in particular the constraints on the extent to which a common policy of support for the CEECs would lead to a generous accommodation of CEEC interests in EC policy. First, the material bargaining power of the CEECs vis-à-vis the EC and the member states was weak. 
Second, policy was constrained, especially with regard to the CEECs' membership perspective, by the perception in certain member states of long-term risks for their position, in terms of their relative influence, their material benefits from membership, and their preferences for the future development of the EC integration process. Third, in particular with regard to trade concessions, domestic sectoral interests and their defence in inter-state bargaining limited the scope for a generous accommodation of the CEECs' interests.

Rationalist predictions also seem correct in identifying the actors who were the primary supporters of a proactive EC policy towards the CEECs. Germany, Italy, and the new member states Austria, Sweden and Finland stand to gain most from political stability and economic opportunities in the CEECs. The UK and Denmark șeem least concerned about a potential negative impact of policy towards the CEECs on the development of the EC integration process. Finally, the key role that the Commission played in the initial EC policy responses could be explained by its interest in asserting its influence on policy and enhancing its position vis-à-vis the member states.

However, while self-interested behaviour is an important aspect of the association policy process, rationalist approaches alone are both inconclusive and cannot explain some of the empirical findings. Rationalist approaches do not offer a clear guide on the interests that "core executives" would promote on concrete issues of trade liberalisation. While it might be argued that accommodation served broader, long term interests, it is not obvious that a subordination of such narrow sectoral interests is a requirement for the achievement of longer term economic and security interests. Furthermore, such a view of enlighted public policy makers does not conform to public choice or liberal intergovernmentalist assumptions about domestic politics, in which public policy makers' preferences are primarily a function of the strongest domestic groups. At an empirical level, too, overriding long-term interests of powerful member states are not an entirely convincing explanation, since German officials, for example, were more often than not arguing for restrictive policy outcomes. Rationalist approaches thus have problems to explain why the CEECs' interests were accommodated to a greater extent than the lowest common-denominator of sectoral interests suggests.

Especially with regard to the membership perspective of the CEECs, rationalist approaches cannot fully explain why policy did continue to evolve after the signing of the EAs. Although there was no dramatic change in the security environment, policy moved towards a much greater accommodation of the demands of the CEECs, with regard to market access and especially with regard to the membership perspective. Why do the member states agree to eventual CEEC membership, even if it is clear that this will challenge some of their interests, both sectoral and budgetary, as well as with regard to future of integration process, both in 
terms of efficiency of decision making, and sustainability of "deep" integration? Furthermore, it must also appear contradictory that the strongest advocacy of the CEECs' demands came in particular from within the Commission, the guardian of "deep" integration.

\section{EU ldentity towards the CEECs and advocacy of accommodating CEEC preferences in EU policy}

The analysis of the development of the association policy suggests that the notion of an EU responsibility for the $\mathrm{CEEC} s$, and a diffuse regulative norm of accommodating the CEECs' interests in EU policy, as part of the EU's collective identity, affected policy primarily through the advocacy of a specific group of policy makers that promoted policy options compatible with this identity. The empirical evidence suggests that there is at least correlation between those policy makers that should be expected to be most receptive to these norms, and those who emerged as a group of policy advocates who promoted the accommodation of the CEECs' interests in EU policy. The remainder of the 'macro-policy makers' was collectively receptive to their arguments, and either broadly supportive, or at least unobstructive to their initiatives.

Receptiveness would be expected to be greatest among those policy makers who represent the EU externally, interact with the CEECs in this function, and identify most closely with the EU. The group of policy advocates was primarily based within the Commission, including the commissioners responsible for external relations, and DG $I$, in particular the unit dealing with policy towards the CEECs. This group supported an accommodation of the CEECs' interests not only because of far-sighted self-interest, but for its own sake. This does not necessarily imply altruism, but rather action according to appropriate behaviour. The second group includes the member states' foreign ministers and heads of state or government. Both groups of policy makers (i.e. the macro-policy makers) were most frequently the source of statements acknowledging and asserting a special role of the EU towards the CEECs. In particular the policy advocates frequently justified policy preferences with reference to norms of accommodation. Other policy makers were compelled into behaviour in accordance with such norms by such references, or to justify deviation from such behaviour with reference to competing norms, rather than idiosyncratic self-interests.

Initiatives for the development of policy, and firmest advocacy of an accommodation of the preferences of the CEECs in EU policy emanated primarily from the commissioners for external relations and their cabinets - Frans Andriessen, and later Leon Brittan - and DG I (external relations), specifically DG I-E (later DG I-L), the unit for relations with the CEECs. The Commission played a key role in the immediate EC policy responses to the unfolding changes in the CEECs in the late 1980s (Trade and Cooperation Agreements, coordinating 
role in the G24 aid; the Phare programme, the EC Action Plan). DG I also very rapidly reacted to the Council's decision of early 1990 to base relations with the CEECs in the framework of association agreements by devising quickly a far-reaching framework for "Europe Agreements" (EAs). During the negotiations of the EAs, and indeed in the internal EC negotiations on the negotiation directives for those agreements and their revision, it was the Andriessen and his cabinet, and the officials in DG I-E who were consistently the strongest advocates of the preferences of the CEECs. On a number of occasions they were able to obtain concessions in the intra-EU negotiations, which took better account of the CEECs' preferences. The initiative for improving the EAs, namely by accelerating trade concessions in the sensitive sectors, and by committing the EC to the objective of the eventual accession of the CEECs, emanated from the Andriessen cabinet. DG I-E officials started on forging a consensus for this immediately after the signing of the EAs. The initiative gained further momentum through the personal commitment of Leon Brittan as external relations commissioner in 1993, leading to the declarations of the Copenhagen European Council. The idea of a pre-accession strategy, which put the principle of the eventual accession of the on a working footing, emerged from a close cooperation between the Brittan cabinet and DG I-L. Endorsement in the Council was achieved through the close cooperation of this Commission team and the German presidency in the second half of 1994.

One way in which the policy advocates and their supporters achieved influence on policy was through affecting the structure of discourse about EU policy towards the CEECs. The reinforcement of a discourse of collective responsibility implied limitations to the perceived legitimacy of arguments relating to the defensive interests of the incumbents. In this respect. the explicit acknowledgement of the CEECs' membership perspective not only reinforced arguments based on the EU's collective identity; it also points at the incentive for the policy advocates to pursue such an explicit acknowledgement as an objective in its own right.

This discourse did not determine outcomes, but limited the realm of acceptable policy options. The importance of the regulative norm and of the terms of policy discourse seem also reflected in the apparent sensitivity and vulnerability of policy makers to criticism of lack of accommodation in the EAs and the association policy. Although not being linked to material resources, the criticism from within the EU, as well as from the CEECs and from the broader academic community (both were at times also strategically elicited by the Commission), seem to have had an impact on policy.

However, an important factor that enabled the policy advocates to influence policy was that it could also draw on the support of arguments relating, and actors receptive to, notions of farsighted self-interest. The suggested complementarity of norm-guided accommodation of the 
CEEC $s^{\prime}$ interests, and of the maximisation of long term self-interests through support of the transformation processes are important. In this respect it is also important that the majority of the policy advocates had a strong background in economics, which enabled them to perceive long term benefits and opportunities, rather than risks, from sectoral competition induced by integration with the CEECs.

\section{Fragmentation and centralisation of the policy coordination process}

Furthermore, the development of the association policy reflects the relevance of the structure of the policy coordination process in mediating the policy impact of the preferences of the macro-policy makers. The lack of continuous oversight by the foreign ministers in the Council, and the disengagement of the European Political Cooperation (EPC) framework from the association policy in early 1990 greatly weakened the scope for more centralised policy coordination. However, in the instances in which policy became insulated at the level of the macro policy makers, accommodation was facilitated. This was apparent during the EA negotiations, when the Commission was able to force the General Affairs Council to become more directly involved in deciding revisions to the negotiations directives. In the lead-up to the Copenhagen European Council, the endorsement of the CEECs membership perspective was decided by the foreign ministers in the Council, acting in considerable autonomy from sectoral policy makers. The package of trade concession announced at the Copenhagen European Council was agreed by a high-level group of foreign ministry officials. The negotiations of the pre-accession strategy were kept at the Coreper level, and decided in a Coreper restraim. The fact that the story of the association policy is so closely linked with specific European Council meetings also reflects the deliberate strategy by the Commission to use the anticipation of the political bias at the European Council to focus attention in the Council.

Apart from these important but rare instances of centralised, hierarchical coordination, the policy process was characterised by a high degree of fragmentation. Negotiated coordination largely took the form of bilateral consultations, in which the meso-policy makers had sufficient autonomy to block concessions in their areas, and policy outcomes were characterised by 'negative coordination.' Neither the Council nor the Commission established multilateral consultation or network structures for the association policy which might have been able to lead to 'positive coordination' and agreement on collective burden sharing. These constraints were apparent in the process of establishing concrete negotiating directives for the Commission. The original framework had been rather far-reaching in accommodating the CEECs' preferences, but the final negotiating directives turned out to be much more restrictive, after the concrete substance of the EAs had to be filled in by sectoral DGs in the Commission, and agreed with sectoral member state policy makers in the Council. Likewise, 
the scope for the CEECs to press for a more far-reaching accommodation of their preferences during the EA negotiations was limited, since these negotiations were characterised by a high degree of fragmentation, and a hands-off approach of the foreign ministers in the General Affairs Council. Fragmentation of the policy process became most pronounced during the implementation of the EAs, which, e.g. made it very hard to resist the use of trade defence instruments.

Only on a few occasions, negotiated coordination reflected elements of 'positive coordination.' In these instances, accommodation was facilitated. In the process of drafting the Commission's proposal for the EA negotiation directives, consultations at the level of directors general led to an agreement to balance the very limited concessions on agriculture with more far-reaching concessions in the other sensitive sectors of textiles and steel. The Commission proposal for a pre-accession strategy was drafted by Brittan and van den Broek in close cooperation with the commissioners Christophersen (economic affairs), van Miert (competition) Steichen (agriculture), and d'Archirafi (internal market). In the process of drafting the Commission White Paper (WP) on regulatory alignment, DG XV initially held weekly meetings with representatives of the other DGs to explain the purpose of the exercise which enabled to a certain extent a more balanced approach in the scope of measures that the latter included into their sections of the WP.

In sum, the analysis of the overall development of the association policy suggests that norms relating to the EU's collective identity towards the CEECs inclined the macro-policy makers towards accommodating CEEC preferences to a certain extent. The main opposition to a more far-reaching accommodation of CEEC preferences was not primarily characterised by national differences among the member states, but came predominantly from sectoral policy makers in the meso areas of the association policy, both within the Commission and within the member state governments. In general, their ability to influence policy outcomes depended on the extent to which the policy process was centralised or fragmented, or to what extent negotiated coordination followed negative or positive coordination between macro - and meso policy makers.

A focus on the overall development of the association policy provides important insights, particularly with regard to the continued evolution of policy towards a policy of enlargement. However, an exclusive focus on this level fails to capture variations in the extent of accommodation of the CEECs' preferences across meso policy areas, as well as the factors that obstructed or facilitated such accommodation. In section 4 of this paper, I have suggested that key factors in this respect concern not simply the strength of interest groups in the different meso areas, as rationalist approaches assume, but also the nature of the respective 
policy paradigms that underpin EU policy in these areas. The following section presents the findings of analyses of two meso policies: the liberalisation of steel trade and the regulatory alignment of the CEECs with the internal market.

\section{Policy in two selected meso policy areas: steel trade liberalisation and regulatory alignment with the internal market}

\section{Liberalisation of steel trade}

The case of EU policy of steel trade liberalisation towards the CEECs shows a significant extent of accommodation of the CEECs' preferences for free and unconditional access to the EU market. Before the negotiations of the EAs, steel trade was governed by a highly restrictive regime of Voluntary Restrain Agreements (VRAs) that imposed both quantitative and price restrictions on CEEC exports. The EAs ended the VRAs, immediately eliminated all quantitative restrictions, and the advocates of the CEECs' preferences in the Commission successfully resisted provisions that would have maintained the possibility to reintroduce VRAs in the future. The greater autonomy of the meso policy makers in the implementation phase meant that on a few occasions EU trade defence instruments were used against CEEC steel producers. Crucially however, the advocates of the CEECs' preferences inside the EU were able to resist interest group pressure for the reintroduction of a restrictive regime as part of the 1993/94 EU plan for the restructuring of the steel industry.

The analysis of policy in this meso area highlights how the emergence of an alternative policy paradigm for EU steel policy that is more compatible with the preferences of the CEECs facilitated accommodation, despite strong opposition from interest groups. In the steel sector, EU producers were strongly opposed to a liberalisation of steel trade with the CEECs, and there was no countervailing pressure from consuming industries. Accommodation of the CEEC preferences for liberalisation was also at odds with the dominant policy paradigm for EU policy, which could be described as a "managed restructuring paradigm." This paradigm is based on the idea that the nature of competition in the steel market is different from other sectors. Firms will only undertake the necessary adjustment and restructuring measures collectively, under guidance from public policy makers and in a stable external environment. In this view, the free play of market forces does merely lead to a cut-throat competition in which not necessarily the most economically viable firms survive.

However, since the early 1990s, an alternative, "non-intervention paradigm" has emerged. This paradigm rejects the idea of the steel sector as a special case. In contrast to the dominant paradigm, external competition is regarded as a positive contributing factor to restructuring. This paradigm places the emphasis no longer on the protection of the EU market, but on the 
need for open markets abroad. This alternative paradigm is thus much more compatible with the C.EECs preferences.

The ascendancy of the "non-intervention" paradigm increased support for a considerable degree of steel trade liberalisation among the meso policy makers, despite strong opposition from organised interests in the sector. Although this alternative policy paradigm emerged largely independently from the association policy, the interaction between advocates of the "non-intervention" paradigm for EC steel policy and the advocates of an accommodating policy towards the CEECs played an important role. The advocates of the non-intervention paradigm provided arguments, and a supportive coalition, for the advocates of a accommodating policy towards the CEECs among the macro-policy makers who were pushing for greater CEEC access to the EC steel market. In turn, references to the need to open EC markets in order to support the CEECs provided an impetus for the ascendancy of the alternative steel policy paradigm in the steel sector.

EU policy for the regulatory alignment of the CEECs with the internal market

The analysis of the regulatory alignment of the CEECs shows that a degree of accommodation of the CEECs' preferences in EU policy was possible, because the advocates of their preferences in the Commission successfully challenged the viability of certain elements of the policy paradigm underpinning the EU's internal market with regard to the specific situation in the CEECs.

The process of regulatory alignment is similar to the process of regulatory harmonisation to remove non-tariff barriers (NTBs) in the Single Market Programme, and to the European Economic Area (EEA) regime that extended the internal market to most of the EFTA countries. Regulatory alignment of the CEECs, as the economic core of the EU's preaccession strategy, was based on a Commission White Paper, endorsed by the Cannes European Council in June 1995. Legally binding decisions in this respect will only be taken in actual accession negotiations.

The challenge of regulatory alignment is of an altogether different magnitude for the CEECs than for the Eftan candidates that were rather similar to the member states in terms of overall economic development, and with their long experience of corporate governance and of operating regulatory regimes. Essentially, the CEECs' interest in the EU's regulatory alignment policy is in selective alignment that allows them to delay adoption of those EU rules that regulate the production process, rather than the nature of products. This concerns the area of EU social policy, e.g. health and safety at the workplace, and some elements of EU environmental policy, such as pollution from stationary sources. These measures might affect 
competition in the internal market, as they affect production costs. But it can be argued they are not essential for the functioning of the internal market, since they do not constitute NTBs that affect the free circulation of products. Selective alignment thus means to implement those measures during long transition periods after accession, rather than at the pre-accession stage

Rationalist approaches identify two main sources of opposition to accommodate these CEEC interests. The first is pressure from EU producers to impose strict compliance with process regulations on CEECs companies from an early stage, in order to reduce the latter's competitive advantage. The second source of opposition are those memiber state governments that are reluctant about an eastern enlargement and could use insistence on extensive alignment and strict and early application of EU regulations as a means to delay the accession of the CEECs. Yet neither the member states in the Council, nor producer lobbies did have a significant influence on the policy process. The drafting of the White Paper to guide the CEECs' alignment was kept closely inside the Commission, and the member states had very little time to discuss the detail of the White Paper that the Cannes European Council endorsed

Yet, two main elements of the EU's internal market paradigm militate against an accommodation of the CEEC.s' interest in selective alignment. The first element is a distinctive understanding of the nature of economic competition, reflected in the endorsement of the "level-playing field" argument. This argument suggests that "fair" competition requires not only the harmonisation of regulations that regulate product standards, but also of those that regulate production processes. Significantly, this argument is not generally accepted among economists, but dominates the EU discourse on the internal market. The second element is a general acceptance inside the EU that the internal market is not merely based on a rationale of competition and market integration, but that it also serves the protection of broader public policy objectives, notably high levels of social and environmental protection. In sum, both these elements of the EU's internal market paradigm constrain the extent to which EU policy makers perceive the CEECs' demands for selective alignment feasible and legitimate.

Nonetheless, the Commission's White Paper accommodates the CEECs' preferences to a significant extent. The EU's regulatory alignment policy was essentially driven by a small team of policy makers inside the Commission, composed of officials from the CEEC unit in DG I and from the cabinet of Leon Brittan, the external relations commissioner. These policy makers' understanding of the specific situation in the CEECs led them to question the viability of the EU's internal market paradigm. They convinced the policy makers of DG XV, responsible for the internal market and the drafting of the White Paper, to take a selective approach. Thus, the single market measures outlined. in the White Paper essentially concentrate on product regulations and exclude process regulations. This selective approach 
is most clearly reflected in the area of environmental policy, where such process regulations as the pollution from stationary sources are excluded from the White Paper. Opposition to the selective approach came primarily from inside the Commission, notably DG V, responsible for social policy. DG $V$ insisted on the inclusion of process regulations, such as health and safety at the workplace. Significantly, these concerns were presented in reference to the EU's internal market paradigm, which in turn made it hard for DG XV to deny their legitimacy.

\section{Conclusions}

I have argued in this paper that by taking account of two different types of institutional or sociological factors, certain policy outcomes and aspects of the development of the association policy can be captured, which rationalist approaches cannot explain.

First, I have highlighted the importance of EU identity towards the CEECs. Norms that are part of the macro-policy makers' collective self-image as representatives of the EU towards the CEECs' incline them towards accommodating the CEECs' preferences in EU policy. These norms have forged a group of advocates of the demands of the CEECs inside the EU that has consistently pushed for a more far-reaching accommodation on issues of policy substance, and for an evolution of the association policy towards an enlargement policy. The perceived need to comply with these norms has limited the extent to which member state foreign ministers and heads of state could refuse the legitimacy of the demands of the CEECs. In general, this has led to a much more far-reaching accommodation of the CEECs' preferences in EU policy than rationalist approaches would predict.

Second, I have emphasised the role of policy paradigms that shape the preference formation of meso-policy makers, independently from interest group pressure, in the different areas of the association policy. In the case of regulatory alignment of the CEECs with EU social policy, the predominant internal market paradigm has constrained the scope for accommodating CEEC preferences, despite only weakly articulated interest group pressure at this stage. By contrast, the emergence of an alternative policy paradigm for EU steel policy, separately from the development of the association policy, has facilitated accommodation, despite strong opposition from steel producers. In the case of regulatory alignment with EU environmental policy, the ability of the advocates of the CEECs' demands inside the EU to challenge the predominant internal market paradigm has opened a window of opportunity for a more farreaching accommodation of the CEECs' interest in selective alignment during the preaccession phase.

As the main conceptual point, I have suggested the use of the concept of a "composite policy" as a framework of analysis for the association policy. The usefulness of this concept rests 
primarily on two points. First, I have emphasised two aspects of the structure of the composite policy that mediate the policy impact of the macro policy makers: the degree of centralisation/fragmentation of the policy coordination process between macro- and mesopolicy makers, and the compatibility of the meso-policy paradigms with the policy options preferred by the macro policy makers.

Second, the concept of a composite policy allows to capture the collective differences between different groups of policy makers in EU policy making that cuts across a national cleavage. I have used the concept to distinguish between analytically distinct institutional factors that shape the preference formation of different groups of policy makers at the macro-policy level (collective EU identity towards the CEECs) and meso-policyi levels (the respective policy paradigms). These collective institutional effects might be used to explain the emergence of collective differences between groups of national and Commission policy makers at different vertical and horizontal levels that seem in certain cases more pronounced than the differences according to national lines. It suggests that under certain conditions transgovernmental alliances and a "governance cleavage" might be more characteristic of the policy debate in the EU than national cleavages and inter-state bargaining. 
Ulrich Sedelmeier: paper for ECSA $6^{\text {th }}$ Biemnial International Conference; Pittsburgh, 3-5 June 1999

\section{References}

Elorza, Javier (1997): New Members - A Southern View, Challenge Enlargement (The European Policy (entre), January 1997, pp. 9-10.

Evaus, Peter B., Dietrich Rueschemeyer and Theda Skocpol (eds.) (1985): Bringing the State Back In (Cambridge: Cambridge University Press)

Friis, Lykke (1997): When Europe Negotiates. From Europc Agrcements to Eastern Enlargement, PID Thesis, University of Copenhagen.

Guggenbuhl, Alain (1995): The Political Economy of Association with Eastern Europe, in Laursen (ed.) (1995), 211-282.

Haggard, Stephan, Marc A. Levy, Andrew Moravcsik and Kalypso Nicolaïdis (1993): Integrating the Two Halves of Europe: Theories of lnterests, Bargaining, and lnstilutions, in Keolane, Nye and Hormann (eds.) (1993), 173-195.

Hall. Peter A. (1993): Policy Paradigms, Social Learning, and the State. The Case of Economic Policymaking in Britain, Comparative Politics, 25: 3. pp. 275-296.

Héritier. Adriemue (ed.) (1993): Policy-Analyse. Politische Vierteljahresschrift Sonderheft 24 (Opladen: Westdeutscher Verlag).

Hix, Simon (1994): The Study of the Europcan Community: The Challenge to Comparative Politics, West European Politics, 17: 1, pp. 1-30.

Katzenstein, Peter J. (ed.) (1996c): The Culture of National Security. Norms and Indentity in World Politics (New York: Columbia University Press).

Keohane, Robert O. (1991): Empathy and International Regimes, in Mansbridge (ed.) (1991), pp. 227-236.

Klotz, Audie (1995): Norms Reconstituting Interests: Global Racial Equality and U.S. Sanctions against South Africa, International Organization, 49:3, pp. 451-478.

Lamers, Karl (1995): Facing the IGC '96, speecl at the Royal Institute of International Affairs, London, 19.10.1995

Laursen, Finn (ed.) (1995): The Political Economy of European Integration (The Hague: Kluwer).

Mansbridge, Jane J. (ed.) (1991): Beyond Self-Interest (Chicago: University of Chicago Press)

Mayntz, Renate (1993): Policy-Netzwerke und die Logik von Verhandlungssytemen, in Héritier (ed.) (1993), pp. 39-56.

Moravcsik, Andrew (1993): Preferences and Power in the European Community: A Liberal Intergovernmentalist Approach, Journal of Common Market Studies, 31:4, pp. 473-524.

Niblett. Robin C. H. (1995): The European Community and the Central European Tluree, 1989-92: a Study of the Community as an International Actor, Ph.D. thesis, Oxford.

Nicolaïdis, Kalypso (1993): East European Trade in the Aftermath of 1989: Did International Institutions Matter? in Keohane, Nye and Hoffmann (eds.) (1993), 196-245.

Price, Richard and Nina Tannenwald (1996): Norns and Deterrence: The Nuclear and Chemical Weapons Taboos, in Katzenstein (ed.) (1996), pp. 114-152.

Scharpf, Fritz W. (1993): Postitive und negative Koordination in Verhandlungssystemen, in Héritier (1993), pp. 57-83.

Shaffer. Matthew R. (1995): The Applicability of Three-Level Gaine Analysis to EC-Visegrad Negotiations for the Europe Agreements, paper presented at the UACES Research Conference, Birmingham, September 1995.

Torreblancha Payá, José Ignacio (1997): The European Community and C.cntral Europe (1989-1993j: Foreign Policy and Decision-Making, PlD Thesis Instituto Juan March de Estudios e Investigaciones (Madrid: Ediciones Peninsular). 